Article

\title{
Teaching Socrates, Aristotle, and Augustine on Akrasia ${ }^{1}$
}

\section{J. Caleb Clanton}

Department of History, Politics, and Philosophy, Lipscomb University, One University Park Drive, Nashville, TN 37204, USA; E-Mail: caleb.clanton@lipscomb.edu; Tel.: +1-615-966-5727

Academic Editors: Scott McGinnis and Chris Metress

Received: 12 December 2014 / Accepted: 31 March 2015 / Published: 9 April 2015

\begin{abstract}
A long-standing debate among moral philosophers centers on the question of whether ignorance is always at the root of moral wrongdoing, or whether, in certain cases, wrongdoing stems from something else-namely akrasia. This paper is a discussion of how undergraduate core curriculum teachers can incorporate Augustine's work into this debate. I begin by briefly reconstructing Socrates' and Aristotle's accounts of wrongdoing, and then I sketch an Augustinian approach to the issue. Socrates contends that ignorance is the fundamental source of all wrongdoing; hence, akrasia is illusory. Though Aristotle's view can seem more roundabout than Socrates', it, too, is plausibly interpreted as entailing that robust, open-eyed akrasia is impossible. For Augustine, prior to receiving the illumination that comes with God's grace, an individual's sinfulness can be characterized as being the result of ignorance concerning the proper focus of one's love. However, after receiving this illuminating grace, sinful action can be characterized as an instance of akrasia.
\end{abstract}

Keywords: Augustine; akrasia; pedagogy; ethics

\section{Introduction}

The great twentieth century theologian Reinhold Niebuhr is often quoted as having said that "original sin is the only empirically verifiable doctrine of the Christian faith" ([1], p. 24). To be sure, there are any number of ways one might wish to challenge Niebuhr's claim. An ambitious apologist, for instance, might try her hand at showing that there are other Christian doctrines beyond original sin

1 This is a revised version of a paper presented at the "Teaching the Christian Intellectual Tradition" Conference on Augustine, Samford University, Birmingham, AL, USA, 2-4 October 2014. 
that are empirically verifiable. Alternatively, one might simply reject the notion that sinfulness or moral culpability is in any way original to the human condition or otherwise inherited from one's ancestors. At any rate, virtually all such quibbling ends if we interpret Niebuhr's claim as asserting merely that every individual — if given enough time, at least — will at some point find herself guilty of moral wrongdoing. To err is human, after all.

Nonetheless, supposing we have all erred and fallen short of moral perfection, it is less obvious as to why. What, broadly speaking, leads us to act wrongly? Why do we sometimes do precisely what we ought not do? Why do we sometimes fail to do those things we should have done? As gloomy as these questions can seem, it is easy enough to see why we should seek the answers: if we can better pinpoint the fundamental source of our moral failings, we should be better able to tackle the challenges associated with moral education, punishment and rehabilitation, and personal discipline.

A long-standing debate among moral philosophers centers on the question of whether an agent's ignorance vis-à-vis what is best is really at the root of every instance of moral wrongdoing, or whether, in some cases at least, wrongdoing stems from akrasia, or what commonly gets described as weakness of will or incontinence. To reframe the question just a bit: Is an intellectual failure of some sort—say, a failure to obtain knowledge or correct belief with respect to the good or the right - always the main driving force behind an agent's moral wrongdoing? Or, are there cases where an agent's wrongdoing is the result of an affective or volitional failure? Is it possible for a person to be fully aware of what she should do, but nonetheless fail to do it? Or is one's failure to act as she should a clear indication that she simply lacked the relevant moral knowledge in the first place?

Socrates and Aristotle are, of course, loci classici for discussion of questions like those, and it is fitting for teachers to turn to their work in undergraduate core curriculum courses. But their views can sometimes leave students-particularly religious believers - with the impression that something important has been left out of the discussion. Fortunately, Augustine can supplement this discussion in a way that addresses at least some of the concerns students may have when considering the Socratic and Aristotelian accounts. The point of this essay is to outline in very rough form how teachers might incorporate Augustine's work into discussions about the source of moral wrongdoing. In what follows, I briefly sketch a way of positioning Augustine as a counterpoint to Socrates' and Aristotle's well-known analyses of wrongdoing. This should not be taken to imply that Augustine saw his treatment of wrongdoing as a response to Socrates and Aristotle; but there is certainly pedagogical value in viewing it in that light. To be perfectly clear, my objective here is not to engage in the penetrating analysis and painstaking scholarship most characteristic of the literature in classical philosophy; nor do I mean to be advocating for Augustine's account of wrongdoing over those of Socrates and Aristotle. Rather, my aim is simply to outline how core curriculum teachers might turn to Augustine, as one of the chief representatives of the Christian intellectual tradition, to inform an important debate in the broader Western intellectual tradition.

To set the stage, it might be helpful to say a little something about the word akrasia. As mentioned above, akrasia sometimes gets translated as "weakness of will" and sometimes as "incontinence". While these translations are helpful for moving us in the right direction, unfortunately, they are imperfect. On the one hand, translating akrasia as "weakness of will" is probably somewhat anachronistic when talking about Socrates and Aristotle, in part because they probably did not have a robust conception of will in the way we do today. On the other hand, translating akrasia as 
"incontinence" can present unnecessary distractions, given that word's association with difficulties related to the bathroom. For these reasons, it makes sense to leave the term akrasia as it is and, instead, simply offer a working definition of it.

Scholars define akrasia in various ways, but for our purposes we can capture the common gist of these definitions in the following manner:

AKRASIA: The condition in which you know (or otherwise correctly believe) that you should $\Phi$, but — against your own better judgment—you do not $\Phi$.

I turn now to Socrates's analysis of wrongdoing in Plato's Protagoras.

\section{Socrates on Akrasia}

Socrates asks his interlocutor, Protagoras, whether knowledge is like "a slave, pushed around by all the other affections" such as passions, pleasure, pain, love, or fear ([2], 352c). Now, the million-dollar question Socrates is posing here is whether knowledge-particularly knowledge of the good or the right - is fully capable of ruling a person such that, if she truly knows what is best, she will act on that knowledge. If a person can have knowledge but not act on it, then clearly knowledge can be overruled by such things as emotions, passions, appetites, and like. Protagoras responds to Socrates by asserting that wisdom and knowledge are "the most powerful elements in human life" and, of course, Socrates quickly agrees ([2], 352d). However, Socrates conjectures that most people do not agree with them on this matter. The masses, he says, believe that people sometimes "recognize the best, but are unwilling to act on it" ([2], 352d-e). In other words, popular opinion holds that an individual can suffer from akrasia: a person can have knowledge of the best course of action but still be overcome by some affection, whereupon she ultimately fails to act in accordance with her own better judgment. Consequently, if the masses are correct, knowledge does, or at least can, get pushed around like a slave.

For Socrates, though, the masses are simply mistaken, because what seems like akrasia is really just an illusion. Admittedly, it can sometimes seem to us that an agent correctly discerns what is best but nonetheless fails to do it (such that the agent is akratic). However, in Socrates' view, the agent who does not do what is best actually just fails to grasp correctly what the best course of action is.

Suppose that some action $R$ is, objectively speaking, the best course of action and that $W$ is not. And suppose further that someone reports to us that she recognizes that $R$ is the best course of action but that - due to the pull of some passion or fit of emotion — she chooses to do $W$ instead of $R$. Although we might be tempted to think that she is suffering from akrasia in the moment, in Socrates' view, what is really going on here is that this person is choosing $W$ over $R$ because, in that moment at least, she simply judges $W$ to be the best course of action to take. Accordingly, the problem is not that she lacks command over herself; the problem is that she fails to believe correctly: she is ignorant about the best course of action. If she had really believed that she should choose $R$ over $W$, then she would have done $R$. Socrates claims, for example, that

no one willingly goes to meet evil or what he thinks to be evil. To make for what one believes to be evil, instead of making for the good, is not, it seems, in human nature, and when faced with the choice of two evils no one will choose the greater when he might choose the less ([2], 358c-d). 
If Socrates is right that we always act in accordance with what we ourselves judge to be good, then, when it comes to wrongdoing, what might appear to be akrasia is really just the output of the agent's misjudgment concerning the various goods and evils or pleasures and pains at stake. This misjudgment results in her believing incorrectly concerning the proper course of action, which, in turn, results in her wrongdoing. So the failure at play is a failure to grasp correctly what is best.

Fittingly, Socrates's solution is to advocate for better all-things-considered judgment, or what he thinks of (in his conversation with Protagoras, at least) as the art of good measurement. He says, for example, that we should

...like an expert in weighing, put the pleasures and the pains together, set both the near and distant in the balance, and say which is the greater quantity. In weighing pleasures against pleasures, one must always choose the greater and the more; in weighing pains against pains, the smaller and the less; whereas in weighing pleasures against pains, if the pleasures exceed the pains, whether the distant, the near, or vice versa, one must take the course which brings those pleasures; but if the pains outweigh the pleasures, avoid it ([2], $356 b-c)$.

Presumably, if we practice this sort of measurement properly in every situation, we will better arrive at correct beliefs concerning what is best, which should ultimately prevent wrongdoing. Of course, at the heart of Socrates's account here is the assumption that we always desire what we take to be good [3]. If it is true that we always desire what we believe to be good, then when a person chooses one course of action over another, she simply chooses what she judges to be best. Hence, wrongdoing comes about only as a result of the agent's miscalculation. To know the good is to do the good. Accordingly, Socrates concludes in his conversation with Protagoras that when a wrong action is done, it is done out of ignorance ([2], 357d). He reiterates the general point in Plato's Gorgias when he declares: "As for me, if I act wrongly at all in the conduct of my life, you may be assured that my error is not voluntary but due to my ignorance" ([4], 488a; emphasis added).

Clearly, then, Socrates denies the possibility of akrasia. This is because, in his view, wrongdoing always stems from a misjudgment, and that as opposed to a lack of self-control or a weakness in the face of one's impulses or emotions. Wrongdoing, then, stems most fundamentally from an intellectual failure. After all, a person's desires are always directed toward what she takes to be good; but whether she really has knowledge of the good at the time of action is a different story.

\section{Aristotle on Akrasia}

Aristotle responds to Socrates' account of wrongdoing in Book VII of the Nicomachean Ethics. There, he contends that Socrates' view, "contradicts things that appear manifestly" ([5], 1145b28). In other words, Socratic intellectualism conflicts with what we seem to experience in our workaday lives - namely, knowing that you should do something, but not doing it (or, alternatively, knowing that you should not do something, but doing it anyway). For Aristotle, a different methodological approach is called for:

The proper procedure will be the one we have followed in our treatment of other subjects: we must present phenomena, <that is, the observed facts of moral life and the current 
beliefs about them, $>$ and, after first stating the problems inherent in these, we must, if possible, demonstrate the validity of all the beliefs about these matters, and, if not, the validity of most of them or of the most authoritative. For if the difficulties are resolved and current beliefs are left intact, we shall have proved their validity sufficiently ([6], 1145b5).

The idea here is that the proper way of proceeding is to start with the datum of our experience-in this case, the appearance of akratic behavior - and try, if possible, to validate our ordinary beliefs about it - the belief, say, that akrasia is a real enough phenomenon. Put differently, we should start with an assessment of our everyday experience and work our way up to a philosophical theory, as opposed to the other way around.

So how might we explain what appear to be akratic behavior? A noteworthy feature of Aristotle's multifaceted treatment of this issue comes to the surface in his discussion of practical syllogisms. We can think of a practical syllogism as the line of thinking that links an agent's moral deliberations with her practice. Accordingly, the premises of a practical syllogism, if true, recommend a certain course of behavior. Now, as Aristotle sees things, practical syllogisms contain at least two premises, namely the universal premise and the particular premise. We can most easily elucidate the distinction between the universal and particular premise by means of Aristotle's own example. A universal premise would be something akin to the claim that "everything sweet must be tasted". A particular premise would be something akin to the claim that "this thing here is sweet". Thus, the practical syllogism Aristotle has in mind here would look like this:

UNIVERSAL PREMISE ……………...... 1. Everything sweet must be tasted.

PARTICULAR PREMISE …………...... 2. This thing here is sweet.

PRACTICAL CONCLUSION ……...... $3 . \therefore$ [The free \& rational agent tastes the sweet thing in question]

If a person works through this sort of syllogism properly, then she will inevitably eat the sweet thing in question because, as Aristotle writes, "it is necessary for someone who is able and unhindered also to act on this at the same time" ([5], 1147a30).

The problem, though, is that a person may very well be hindered with respect to grasping the particular premises, precisely because "perception controls them" ([5], 1147a27). In other words, sense perception in some way influences a person's evaluation of the particular premise in a practical syllogism. And because sense perception is involved in the evaluation of a particular premise, a person may very well be affected by an onslaught of passion or emotion in her assessment of that particular premise. Accordingly, it is possible for a person to have knowledge about the universal premise - she could know, for example, that everything sweet must be tasted-but nonetheless fail to taste the particular sweet thing in front of her, precisely because some sort of pathos impaired her sense perception in assessing the particular premise. Hence, the person's wrongdoing in this case is seemingly akratic: she knows that she should $\Phi$, but—against her own judgment on some level—she does not $\Phi$. More precisely, she has deliberated properly at the level of the universal premise (thus she correctly grasped on some level what is best), but she has failed to reach the proper practical conclusion of that deliberation because some pathos affected her assessment of the particular premise.

Ultimately, then, for Aristotle, the apparently akratic person can be characterized as having some sort of knowledge of the good (viz., knowledge of the universal premise). But this knowledge is clearly not enough to prevent wrongdoing. Because the apparently akratic person has only propositional 
knowledge of the universal premise, she does not act on it due to some sort of weakness. In this sense, as Aristotle sees it, the apparently akratic person is "like a city that votes for all the right decrees and has excellent laws, but does not apply them" ([5], 1152a20).

We are right, however, to wonder whether the apparently akratic person in Aristotle's account really and truly has knowledge of what is best. In turn, we are right to wonder whether Aristotle's apparently akratic person is genuinely and robustly akratic on final analysis. He admits, for example, that the sort of knowledge he attributes to the apparently akratic person "is not the sort that seems to be fully knowledge" ([5], 1147b16-17; emphasis added). Thus, if we take Aristotle at his word here, it seems that there is at least some component of full knowledge that the apparently akratic person lacks. Accordingly, in some important sense, the agent in question is still ignorant of what is best, so the agent's wrongdoing seems to stem fundamentally from an intellectual failure after all.

For Aristotle, a more robust conception of knowledge-full knowledge of the good in this case-seems to be what he refers to as prudence or practical wisdom. Knowledge qua practical wisdom is where one both correctly grasps how she should behave and also acts in accordance with that awareness ([5], 1152a8-9). As such, Aristotelian practical wisdom seems roughly similar to what Socrates takes knowledge of the Forms, in general, to be. For Socrates, genuine knowledge of the Forms amounts to a sort of conversion experience, such that if one really has knowledge of the Forms, she is so drawn to the good that she is compelled to act accordingly ([7], 518d-19a). Along similar lines, Julia Annas contends that the

...Forms are...more than theoretical entities in a theory that explains the phenomena; a knowledge of them is part of the good person's understanding. Plato sometimes (though not in the Republic) talks of one's ascent to the Forms as being one of love and desire, as though the Forms had an attractive force. But this should not be misunderstood: the Forms are not equally attractive to the philosopher and to the clever ruthless exploiter. Rather, Plato thinks that no amount of intelligence will grasp the Forms if it is directed to self-interested and narrow ends ([8], p. 237).

Following Annas, we might say that, for Socrates, if one "knows" the Forms in merely some truncated sense - in what amounts to nothing more than a cognitive grasp of correct propositions - then that person does not really have knowledge of the Forms in any robust sense. And Aristotle's conception of knowledge qua practical wisdom seems to align with this robust Socratic conception of knowledge of the Forms.

So perhaps, then, we should read Aristotle as agreeing with Socrates' conception of knowledge on final analysis - that is, if we take knowledge qua practical wisdom to be what Aristotle means by full or complete knowledge. Robert Solomon contends, for example, that Aristotle indeed adopts the Socratic conception of knowledge at 1152a8-9. So if it is true that Aristotle adopts this Socratic conception of knowledge, then Aristotle's account of wrongdoing, like Socrates', would imply that full-blown akrasia is impossible. Solomon writes:

Aristotle's use of "knowledge"... is such that no room is left for akrasia, for if one acts wrongly, he is, by definition, not practically wise, and thus Aristotle is, in fact, denying akrasia in the same manner as Socrates, viz., both claim that the phenomenon of akrasia is 
illusory, for by definition, one cannot act wrongly if he has the appropriate knowledge ([9], p. 15).

Ultimately, then, the question of whether Aristotle's account of wrongdoing allows for the possibility of full-blown akrasia seems to turn on the relevant conception of knowledge attributable to him. If Solomon is right, Aristotle adopts the Socratic conception. And if that is correct, then Socrates and Aristotle ultimately agree that robust, open-eyed akrasia is impossible. To Solomon's credit, Aristotle himself hints at this interpretation of his view when he admits that, insofar as having knowledge of the universal premise alone would not entail having knowledge to the fullest extent, "even the result Socrates was looking for would seem to come about" ([5], 1147b15). Thus, it seems that Socrates and Aristotle agree that, in every instance of wrongdoing, some form of ignorance is the fundamental source of wrongdoing and, hence, that full-blown, open-eyed akrasia is impossible.

\section{Augustine on Akrasia}

Undergraduates sometimes want to resist the Socratic and Aristotelian accounts of wrongdoing, in part because they find the conclusions of those accounts counterintuitive. Their perplexity is enough to reproduce: How can it be that the fundamental root of every wrongdoing is intellectual in nature? Is it not the case that at least some instances of wrongdoing are attributable to problems of the heart, so to speak, and not just problems of the head? In any case, it is unclear that Socrates and Aristotle settle the score on this issue, even if it can be difficult to spot where they go wrong. Fortunately, Augustine offers a sufficiently different approach to the matter, one that may help teachers broaden the discussion.

Now, unlike Socrates, Augustine seems assume that akrasia is possible precisely because he thinks it is actual. Consider, for example, his famous depiction of what can seem to be wantonly akratic behavior from his own teenage years:

There was a pear tree near our vineyard, heavy with fruit, but fruit that was not particularly tempting either to look at or to taste. A group of young blackguards, and I among them, went out to knock down the pears and carry them off late one night, for it was our bad habit to carry on our games in the streets till very late. We carried off an immense load of pears, not to eat - for we barely tasted them before throwing them to the hogs. Our only pleasure in doing it was that it was forbidden. Such was my heart, O God, such was my heart: yet in the depth of the abyss You had pity on it. Let the heart now tell You what it sought when I was thus evil for no object, having no cause for wrongdoing save my wrongness. The malice of the act was base and I loved it - that is to say I loved my own undoing, I loved the evil in me — not the thing for which I did the evil, simply the evil: my soul was depraved, and hurled itself down from security in You into utter destruction, seeking no profit from wickedness but only to be wicked ([10], II.iv.9).

Would this theft constitute an instance of genuine, open-eyed akrasia? To address this question, we should pause to consider the reasons the young Augustine may have had for stealing the pears ([11], p. 189).

Augustine labors throughout much of Book 2 of his Confessions to identify the underlying motive for his behavior. Did he steal the pears out of need, or perhaps out of a desire to improve his 
personal holdings? No. Was it for the pleasure of tasting the pears or for the beauty of the stolen fruit? No - after all, he barely even tasted them and, besides, he had even better pears of his own. Was his theft aimed at winning the approval of his blackguard companions, or perhaps to elicit a good laugh? Again, no and no. Admittedly, Augustine insists that he would not have committed the crime had he been alone at the time. And even though he surmises that his "friendship unfriendly" somehow contributed to his desire to commit the crime, he is not convinced that he stole the pears for the sake of the crowd ([10], II.viii.16).

Is there simply no remaining explanation for why the young Augustine stole the pears? Was he simply akratic?

Maybe not. After all, Augustine hypothesizes that perhaps his motive was simply "the thrill of acting against Your [God's] law - at least in appearance, since I had no power to do so in fact, the delight a prisoner might have in making some small gesture of liberty — getting a deceptive sense of omnipotence from doing something forbidden without immediate punishment" ([10], II.vi.14; emphasis added). Now, suppose we extend Augustine's hypothesis here. Perhaps the young Augustine thought that the excitement of defying God - together with the exhilaration of vainly trying to place himself above God's authority — was just so titillating that he judged in the moment that stealing the pears was, all things considered, the best course of action. If the young Augustine had reasoned in this way, then the fundamental source of his wrongdoing would not have been akrasia, but simply an erroneous judgment about what was best (viz., the mistaken belief that the thrill of defying God trumps obedience to God's law).

Of course, there is a rather big if afloat here because Augustine does not actually indicate that he reasoned through the matter in the way imagined. Instead, he tells us that he stole the pears simply because doing so was forbidden and evil — and not for the thing for which the evil was done. What distresses him about this fact is that it seems to Augustine that evil itself could not be the end for which he acted: "Could you find pleasure only in what was forbidden, and only because it was forbidden?" ([10], II.vi.14). Presumably not. As T. D. J. Chappell notes, "such a motive [doing $\Phi$ because it is forbidden] seems to him [Augustine] hardly an adequate reason for doing anything!" ([11], p. 189). This is because, as Chappell contends, Augustine affirms the directedness thesis according to which "all voluntary action is rational in the sense of being necessarily directed towards some good or other" ([11], p. 189). The implication, then, is that Augustine's theft was simply inexplicable; to explain it would require a description of the good at which it was aimed, and Augustine has come up short. It appears, then, that the only thing left to say is that the young Augustine suffered from a bad will. Thus, the specter of akrasia looms large.

Leave the pear tree episode to the side. At this juncture, it will be helpful to take a step back and appreciate the teleological eudaimonism of Augustine's moral philosophy. For Augustine, the chief end of all human endeavors is to attain happiness - we all desire to live happily, he says ([12], p. 153). Of course, whether a person obtains happiness is ultimately contingent on her various pursuits in life. Augustine characterizes these pursuits as being indicative of what a person really loves: he says, for example, "Pondus meum amor meus"-or "my weight is my love" ([13], p. 134). Hence, as Étienne Gilson notes, the basic moral problem for Augustine, "is not whether one should love, but what one should love" ([14], p. 135). 
The object of a person's love is crucial for Augustine because, depending on its worth and the corresponding manner in which one loves and pursues it, one's will is rendered either good or bad accordingly. If one loves what is supremely good - and if one loves it properly and to the appropriate degree-then she has a good will. Alternatively, if one loves inferior things improperly or disproportionately, then her will is bad to that extent. In turn, the moral quality of a person's behavior is driven by the moral quality of her will.

Ultimately, for Augustine, true happiness can be found only in the proper love and pursuit of God, the highest good. Accordingly, we might characterize sin in his view as the misdirected and inordinate love of non-divine things - things inferior to the God who created them-whereby the will is turned away from God in the process. In effect, then, the sinful will does not appropriately love, and thus does not properly pursue, that which is supremely worthy of its affection. In other words, sin is perversio from God, where one turns toward and inordinately loves God-inferior things as though they were actually worthy of the love that is appropriate only for what is supremely good. Augustine explains, for example, that while such God-inferior things as human friendship are indeed good and admirable:

Yet in the enjoyment of all such things, we commit sin if through immoderate inclination to them-for though they are good, they are of the lowest order of good - things higher and better are forgotten, even You, O Lord our God, and Your Truth and Your Law. These lower things have their delights but no such as my God has, for He made them all: and in Him doth the righteous delight, and He is the joy of the upright of heart. ([10], II.v.10; emphases in original).

Along similar lines, he writes:

[W] hen I now asked what is iniquity, I realised that it was not a substance but a swerving of the will which is turned towards lower things and away from You, O God, who are the supreme substance: so that it casts away what is most inward to it and swells greedily for outward things ([10], VII.xvi.22; emphasis added).

This is a key passage because it shows that, for Augustine, sin is not a substance created by God. After all, God is omnibenevolent and, thus, cannot be the efficient cause of sin or evil. Rather, sin is a privation of good that occurs when the will turns away from God. Along similar lines, Augustine explains in City of God that "the bad will is the cause of bad action" and that nothing beyond the will itself accounts for the badness of the will in question ([12], p. 159). In short, the will becomes bad by "wickedly and inordinately desiring an inferior thing" ([12], p. 160). This is not to say that the perverse will is the efficient cause of evil; rather, the point here is that the inordinate love and pursuit of God-inferior things is simply a description of the evil will.

One of Augustine's most significant contributions to the history of philosophy is his very robust notion of the will; but, of course, his take on it is complex. In his view, a person cannot simply freely will to pursue God without God's help. This is because, prior to receiving God's grace, even though the will may be free in some mundane sense, it is inclined toward, and hence encumbered, by sin. Consider, for example, what Augustine says in his Enchiridion: 
For what good work can a lost man perform, except so far as he has been delivered from perdition? Can they do anything by the free determination of their own will? Again, I say, God forbid. For it was by the evil use of his free will that man destroyed both it and himself. For, as a man who kills himself must, of course, be alive when he kills himself, but after he has killed himself ceases to live and cannot restore himself to life; so, when man by his own free will sinned, then sin being victorious over him, the freedom of his will was lost...Accordingly, he who is the servant of $\sin$ is free to sin. And, hence he will not be free to do right, until being freed from sin [by grace], he shall begin to be the servant of righteousness ([12], p. 181; emphasis added).

Prior to receiving God's grace, the will is confined to being turned away from God. As such, an agent is capable of loving and pursuing only those things that are inferior to God; yet the agent loves those things as though they were worthy of the inordinate love that she has for them.

The fundamental problem, so it seems, is that the agent in question is mistaken - that is, she mistakenly assumes that God-inferior things are worthy of her utmost love (the love she should reserve solely for the supreme good, God). Consequently, prior to receiving the illumination that comes with God's grace, an agent's sinfulness can be plausibly characterized as being the result of her ignorance of the fact that God's alone is worthy of her utmost love (and, hence, as a result of her ignorance vis-à-vis the worth of God-inferior things). Construed in this way, pre-illumination sinfulness for Augustine seems to run parallel to the Socratic view that ignorance of what is best is at the root of moral wrongdoing. In other words, the fundamental source of wrongdoing here is intellectual in nature, and not akrasia.

Admittedly, it might be tempting to think that this Augustinian account of pre-illumination sinfulness differs from Socratic intellectualism in an important way that is relevant to the akrasia issue. For Socrates, when a person acts wrongly, she is acting in this way because of her of ignorance. The obvious implication is that, had she not been mistaken in her judgment, she would not have erred. For Augustine, though, pre-illumination agents act wrongly (so one might say) not because they hold incorrect beliefs about what is best, but simply because they love improperly. Prior to receiving God's illuminating grace, agents love, say, sexual pleasure or power or even family in the place of loving God with all their hearts. Thus, so the thought goes, while pre-illumination wrongdoers act perhaps in ignorance, they do not act wrongly because of their ignorance, but because of their inordinate love of God-inferior things.

Note, though, that this sort of move simply shifts the role of ignorance up a level. Why would a person love God-inferior things as though she assumed they were worthy of the love she should reserve for the supreme good? The answer, so it seems, is that she believes that those God-inferior things are worthy of the love they receive (when in fact they are not). Thus, while it is true that pre-illumination wrongdoers are guilty of misdirected and inordinate love, there appears to be a deeper explanation as to why: ignorance concerning what is and is not worthy of one's utmost love seems to be at the root. Accordingly, we might say that pre-illumination wrongdoers act both in and because of their ignorance concerning what is truly worthy of their highest love.

At any rate, this ignorance can be overcome by the divine illumination that comes with God's grace. For Augustine, divine grace involves both a cognitive and a volitional dimension [15]. He writes: 
The grace of God through Jesus Christ our Lord must be understood as that by which alone men are delivered from evil, and without which they do absolutely no good thing, whether in thought, or will or affection, or in deed; not only in order that they may know by the manifestation of the same what should be done, but moreover in order that by its enabling they may do with love what they know ([12], p. 176; emphases added).

The relevant point here is that, through the special and unmerited acts of divine grace, the individual is made aware that God is the highest good (and hence supremely worthy of her deepest affection); moreover, the individual is given the volitional wherewithal to love and pursue God. Augustine hints at this dual nature of grace in even more dramatic, first-personal terms in his Confessions:

Thou [God] didst call and cry to me and break open my deafness: and Thou didst send forth Thy beams and shine upon me and chase away my blindness: Though didst breathe fragrance upon me, and I drew in my breath and do now pant for Thee: I tasted Thee, and now hunger and thirst for Thee: Thou didst touch me, and I have burned for Thy peace ([10], X.xxvii.38; emphases added).

In receiving God's illuminating grace, a person is no longer blind to the fact that God is worthy of one's deepest love nor to the fact that one's inordinate love for God-inferior things should be recalibrated in light of God's supreme worth. Furthermore, the will is emancipated to pursue God, whereas, prior to grace, the will was constrained to pursuing God-inferior things. Augustine refers to this post-grace freedom of the will as "true liberty" ([12], p. 181). The will can now "begin to be the servant of righteousness", take pleasure in righteous pursuits, and freely submit to a "holy bondage" whereby one freely obeys God's will ([12], pp. 181-82).

Nonetheless, despite the fact that divine grace has both a cognitive and a volitional effect on a person, those two effects do not (necessarily) come about simultaneously. In fact, Augustine depicts himself as having been fully aware that God is worthy of his highest love well before he turned his will to love and pursue God with all his strength: "whereas You [God] showed me by every evidence that Your words were true, there was simply nothing I could answer save only laggard and lazy words: 'Soon', 'Quite soon', 'Give me just a little while'.” ([10], VIII.v.12). The period between the cognitive effects of divine illumination and the full volitional transformation brought on by God's grace proves significant with respect to the possibility of akrasia in Augustine's view. Insofar as divine grace illuminates the true and supremely worthy object of one's love, the individual is now no longer unable to grasp what she ought to turn toward and pursue. Hence, Augustine writes: "I no longer had the excuse which I used to think I had for not forsaking the world and serving You [God], the excuse namely that I had no certain knowledge of the truth" ([10], VIII.v.11). Nonetheless, even she who correctly grasps the highest good can still fail to love and pursue it with all her strength - and thus she can fail to live as she should. The wrongdoer in this case appears to be robustly akratic: she correctly grasps that she should love and pursue God, but she fails to do it anyway.

But how could a person grasp what is best, but nonetheless fail to do it? Augustine's answer is to emphasize the residual effects of pre-grace perversio on the will ([16], pp. 93-100). When a person inordinately loves God-inferior things in the place of loving God fully, those perverse desires give way to the cultivation of evil habits, and those habits calcify in such a way that she becomes imprisoned by her old ways of loving God-inferior things. We might say, then, that she becomes encumbered by her 
old delicious burdens (to twist a line from Walt Whitman). Augustine explains in his own case, for example, that

I longed for the same chance [the chance to devote himself to God], but I was bound not with the iron of another's chains, but by my own iron will. The enemy held my will; and of it he made a chain and bound me. Because my will was perverse it changed to lust, and lust yielded to become habit, and habit not resisted became necessity. These were like links hanging one on another-which is why I have called it a chain - and their hard bondage held me bound hand and foot. The new will which I now began to have, by which I willed to worship You freely and to enjoy You, O God, the only certain Joy, was not yet strong enough to overcome that earlier will rooted deep through the years. My two wills, one old, one new, one carnal, one spiritual, were in conflict and in their conflict wasted my soul ([10], VIII.v.10).

Here, Augustine seems to locate the source of his wrongdoing not in the intellect, but in the divided and, hence, weakened will. The individual in Augustine's situation grasps what is best (viz., loving and pursuing God), but her will is compromised at this juncture because it is conflicted. On the one hand, through the volitional gifts of divine grace, the individual is now beginning to will to love and pursue God. On the other hand, the will is haunted by the lingering habits of its pre-grace perversio, and so it still yearns on some level for God-inferior things.

How can the agent overcome this predicament? For Socrates, since the root of wrongdoing is an intellectual failure, the solution is to improve our intellectual position. We might be tempted to think that, by analogy, since intellectual problems have intellectual solutions, perhaps volitional problems would have volitional solutions for Augustine. That is, we might be tempted to think that the solution here is for the agent to will herself out of the situation.

Robert Pasnau explains why this cannot work. He depicts the will in Augustine's work as being "whatever power within us has [the] final conscious responsibility for triggering action" ([16], p. 97). An agent's will, then, is effectively what issues commands to the agent in question. Unfortunately, though, the will may or may not listen to reason in making its commands. For example, the will might command the agent to turn toward and pursue something that clashes with what the agent grasps as best. It may seem, then, that the only recourse that the agent would have in cases where her will is divided (e.g., in case where she wills to love God, but, due to her old habits, she also wills to love God-inferior things inordinately) is simply to rely on another command of her will. Suppose, then, that the agent issues to herself what Pasnau labels a "metacommand"-say, the metacommand to overcome the will's dividedness and to pursue God full tilt. This would avail nothing because, as Pasnau explains

The metacommand [to overcome the conflict in the will] can have no more force than the initial command [to love God full tilt], because the metacommand in effect reiterates the initial command...There is nothing beyond will and reason that can take charge and alleviate the agent's predicament. If one's will is weak, there is no higher executive power on hand to provide further motivation. At that point, all one can do is wait for help to arrive ([16], p. 100). 
For Augustine, the only solution to the problem of a compromised will is, again, God's grace. Grace, so it seems, is needed both for the initiation of the volitional wherewithal to love and pursue God in the first place and for the strengthening in that pursuit so that the agent in question can eventually overcome the residual effects of her old ways of loving.

\section{Concluding Remarks}

Whereas for Augustine an agent's pre-illumination perversio can be plausibly characterized as being the result of ignorance, post-grace perversio would apparently constitute an instance of genuine, full-blown akrasia. Accordingly, in contrast to Socrates and Aristotle, Augustine's account of wrongdoing allows for the possibility that something other than an intellectual failure can be at the fundamental root of an agent's wrongdoing — namely, a compromised will.

Questions remain, though. Is this post-grace perversio an instance of robust, open-eyed akrasia on final analysis? Or should we say that it is actually the result of some deeper sort of ignorance or misjudgment concerning what is best?

One might be tempted to think that, for Augustine, even post-grace wrongdoers as described above are not robustly akratic precisely because they do not (and cannot) have full and complete knowledge of the supreme good (God) in this life. Full knowledge of God would come only in the beatific vision. Thus, the problem of wrongdoing is still a problem of ignorance on some level, or so it may seem.

Still, though, even if an individual could not obtain complete knowledge of God in this life, it does not follow that she could not come to grasp, by means of God's illuminating grace, that God is supremely good and alone worthy of her utmost love and pursuit. And it seems that only the latter-and not the former-would be needed for akrasia to be possible.

So suppose we set that concern to the side. We might still wonder whether post-grace wrongdoers are robustly and genuinely akratic all the way down. In other words, we might wonder whether an intellectual failure, as opposed to a volitional failure, is at the very bottom of Augustine's analysis of wrongdoing. Why is this? Post-grace wrongdoing in his view seems to stem from the lingering effects of the will's pre-illumination perversio from God-the will is divided and compromised because of entrenched habits formed prior to receiving God's illuminating grace. And it is plausible enough to think that at least some of these habits were formed in and because of the individual's pre-illumination ignorance. Accordingly, the most fundamental source of wrongdoing in these cases would seem to be intellectual in nature, even though this intellectual failure does its damage indirectly by means of compromising the will.

If so, then perhaps we are left with questions about whether Augustine's account of wrongdoing moves somewhat more in the direction of Socratic intellectualism than it may initially seem. In any case, I leave these questions for others with the hope that the foregoing sets the stage for a fruitful conversation to come - one that is helpful for core curriculum teachers who are interested in exploring Augustine's work as a way of supplementing discussions of moral wrongdoing. 


\section{Acknowledgments}

For helpful comments on previous drafts of this paper, the author thanks the anonymous reviewers of this journal and the attendees of his paper session at "Teaching the Christian Intellectual Tradition" Conference on Augustine (Samford University, Birmingham, AL, USA, 2-4 October 2014).

\section{Conflicts of Interest}

The author declares no conflicts of interest.

\section{References and Notes}

1. Reinhold Niebuhr. Man's Nature and His Communities. New York: Charles Scribner's Sons, 1965. Niebuhr here, it should be noted, is quoting from the London Times Literary Supplement.

2. Plato. Protagoras. Translated by W.K.C. Guthrie. In The Collected Dialogues of Plato. Edited by Edith Hamilton and Huntington Cairns. Princeton: Princeton University Press, 1989, pp. 308-52.

3. Socrates' assumption (that we all desire the good) is articulated in a number of places throughout Plato's dialogues. For example, Socrates expresses this assumption rather explicitly in conversation with Clinias in Plato's Euthydemus (278e and following). And, in Plato's Apology, Socrates conveys a similar point when he gets Meletus to admit that there is no one who prefers to be harmed (25d-26a).

4. Plato. Gorgias. Translated by W.D. Woodhead. In The Collected Dialogues of Plato. Edited by Edith Hamilton and Huntington Cairns. Princeton: Princeton University Press, 1989, pp. 229-307.

5. Aristotle. Nicomachean Ethics. Translated by Terrence Irwin, 2nd ed. Indianapolis: Hackett Publishing Co., 1985.

6. Aristotle. Nicomachean Ethics. Translated by Martin Ostwald. Upper Saddle River: Prentice Hall, 1990.

7. Plato. Republic. Translated by Paul Shorey. In The Collected Dialogues of Plato. Edited by Edith Hamilton and Huntington Cairns. Princeton: Princeton University Press, 1989, pp. 575-844.

8. Julia Annas. An Introduction to Plato's Republic. Oxford: Clarendon Press, 1981.

9. Robert C. Solomon. "Aristotle, the Socratic Principle, and the Problem of Akrasia." Modern Schoolman 49 (1971): 13-21.

10. Augustine. Confessions. Translated by F.J. Sheed, 2nd ed. Indianapolis: Hackett Publishing Co., 2006.

11. T.D.J. Chappell. Aristotle and Augustine on Freedom: Two Theories of Freedom, Voluntary Action and Akrasia. New York: St. Martin's Press, 1995.

12. Augustine. The Essential Augustine. Edited by Vernon J. Bourke. Indianapolis: Hackett Publishing Co., 1974.

13. Augustine's words quoted in Étienne Gilson. The Christian Philosophy of Saint Augustine. Translated by L.E.M. Lynch. London: Victor Gollancz, Ltd., 1961.

14. Étienne Gilson. The Christian Philosophy of Saint Augustine. Translated by L.E.M. Lynch. London: Victor Gollancz, Ltd., 1961.

15. We might think that we should separate out divine illumination from the volitional aspect of divine acts of grace and reserve the label of grace exclusively for the latter. For example, Robert 
Pasnau characterizes divine illumination as being analogous to the volitional effects of divine grace, though he does not straightaway depict them as dual features of divine grace. See Robert Pasnau. "Divine Illumination." The Stanford Encyclopedia of Philosophy, 2011 Edition. Edited by Edward N. Zalta. Available online: http://plato.stanford.edu/archives/sum2011/entries/ illumination/ (accessed on 23 March 2015).

16. Robert Pasnau. "Plotting Augustine's Confessions." Logos: A Journal of Catholic Thought and Culture 3 (2000): 77-106.

(C) 2015 by the author; licensee MDPI, Basel, Switzerland. This article is an open access article distributed under the terms and conditions of the Creative Commons Attribution license (http://creativecommons.org/licenses/by/4.0/). 